\title{
Is and Ought? How the (Social) Ontological Circumscribes the Normative
}

\author{
Dorothea Gädeke ${ }^{1,2}$
}

Received: 16 April 2019 / Accepted: 12 September 2020 / Published online: 26 October 2020

(c) The Author(s) 2020

\begin{abstract}
Is normative theory grounded in ontology and if so, how? Taking a debate between Kwame Gyekye and Thaddeus Metz as my point of departure, my aim in this article is to show that something normative does indeed follow from ontological views: The social ontological, I maintain, circumscribes the normative without, however, fully determining its content. My argument proceeds in two steps: First, I argue that our social ontological position constrains what kind of normative theory we may plausibly defend. A relational ontology as defended by Gyekye entails a relational normative theory, whereas an atomist ontology calls for an individualist normative approach and a collectivist ontology for a strong communitarian one. Second, this link between the ontological and the normative has substantive implications for how to interpret the normative content of a theory; it entails interpreting normative values in light of the appropriate kind of normative thought. I illustrate the importance of this implication by showing that it suggests a decidedly relational reading of the core value of well-being in Gyekye's moderate communitarianism, that resolves the alleged tension between communal and individual values in his account.
\end{abstract}

Keywords Ontologized ethics · African philosophy · Relationalism · Gyekye · Is-ought-gap

\section{Introduction}

What is the relationship between normative ethics and ontology? Can and should normative ethics be grounded in ontology, and if so, how? Within the AngloAmerican philosophical tradition, there is a longstanding resistance towards

Dorothea Gädeke

d.g.gadeke@uu.nl

1 Department for Philosophy and Religious Studies, Universiteit Utrecht, Janskerkhof 13, 3512BL Utrecht, The Netherlands

2 Department for Philosophy, University of Johannesburg, B Ring, Auckland Park, Johannesburg 2006, South Africa 
justifying normative claims on the basis of ontological ones, both on logical and pragmatic grounds. In contemporary African philosophy, by contrast, the view that normative ethics is directly tied to ontology is widely endorsed. Not surprisingly, this position readily arouses suspicion from philosophers adhering to the claim of keeping normative reflection distinct from ontology. The debate between Kwame Gyekye and Thaddeus Metz exemplifies this confrontation. While Gyekye advances a moral-political theory that is explicitly based on a social-ontological account of how the individual relates to the social, Metz argues that even though Gyekye's normative view might be attractive, it does not derive from the ontological position he defends. In fact, Metz claims that "[f]rom purely ontological claims about what is, one cannot derive any epistemic support for a moral conclusion about what ought to be." (Metz 2014: 200)

Taking this debate as my point of departure, my aim in this paper is to show that something normative does indeed follow from ontology. The social ontological, I maintain, circumscribes the normative without, however, fully determining its content. I start with a clarification of the issue at hand, before reconstructing how Gyekye grounds his moderate communitarianism in a relational social ontology and why Metz criticizes his account as fallacious (2). Against the background of this debate, I will first argue that social ontology may not entail a particular normative content. The social ontological view does, however, commit normative theorists to defend a particular kind of normative thought. A relational social ontology as defended by Gyekye entails a relational normative theory, whereas an atomist social ontology would call for an individualist normative approach and a collectivist social ontology for a strong communitarian one. Secondly, I argue that this link between social ontology and normative theory does have substantive implications insofar as it entails interpreting normative values in light of the appropriate kind of normative thought. To illustrate, I show that my analysis puts Gyekye's central notion of well-being in a different light: It does not merely reflect the individualist side of his moderate communitarianism; rather, the notion of well-being, I maintain, is best understood in relational terms itself (3).

Note that my argument is limited in three important ways. In this paper, I do not defend relationalism (or any other particular social ontological view). My aim rather is to develop an account of how (social) ontology constrains normative theorizing irrespective of the particular ontological view at hand. Moreover, I do not discuss the stronger claim that substantive normative content, like Gyekye's moderate communitarianism, can fully and directly be derived from ontology. I merely show that social ontological considerations constrain the kind of normative theory that can plausibly be defended and that they do have substantive implications for how to interpret normative content. Thus, I provide grounds for taking the link between the normative and the ontological more seriously than often acknowledged within the Anglo-American tradition without however fully capturing stronger views on this link within the African literature. Finally, I focus on the link between social ontology and political morality. This focus is owed to the way Gyekye frames his argument. I cannot analyze how other ontological issues bear on normative ethics in this paper; however, I do briefly address the broader relevance of my argument beyond social ontology in the conclusion (4). 


\section{Ontologized Ethics? The Debate Between Gyekye and Metz}

Can normative theory be grounded in ontology and if so, how? In this section I will introduce the issue at stake by showing how it is framed and answered differently in Anglo-American and African philosophy, respectively (2.1). I then move on to summarize the debate between Gyekye and Metz as an example of how this issue is discussed. I will briefly outline the main features of Gyekye's moderate communitarianism and show how he grounds it in a social ontological view of the dual nature of human beings - a view that I characterize as a relational social ontology (2.2). I will then present the three ways of understanding how exactly the normative is linked to the ontological that Metz discusses and-rightly-rejects (2.3). The exposition of Gyekye's position and Metz' criticism serves to prepare the ground for my alternative proposal of how the normative and the social ontological are related in the subsequent section.

\subsection{Ontology and Normativity_Framing the Issue}

As noted at the outset, within the Anglo-American philosophical tradition, there is a longstanding resistance towards theorizing normative claims as somehow bound up with ontological issues. At least two different reasons motivate this resistance: First, ever since Hume famously articulated what later became known as the naturalistic fallacy (Hume 2000; Moore 1903), philosophers have been wary of linking normative judgments to truth claims about what is in the world. While there is controversy about how best to interpret Hume's or Moore's initial statement of the problem, the core concern is that moral conclusions cannot logically be derived from purely descriptive premises without relying on at least an implicit normative premise. There is, in other words, a gap between 'is' and 'ought'.

To be sure, ontological claims are not usually understood in terms of empirical descriptions of the world of the kind Hume had in mind. While both are concerned with what there is, in the world, the kind of $i s$ they address is different: on the one hand, the empirical description of given states of affairs, and on the other the often a priori ontological inquiry into the most fundamental buildings blocks of existence. How exactly the relation between the two is conceived depends on the metaethical position one holds. ${ }^{1}$

What matters, however, regarding the resistance towards grounding normative claims in ontological ones is less the nature of the descriptive claim made but rather the distinction between a descriptive and a normative claim, irrespective of the nature of that description. Insofar as ontological claims seek to answer the question what exists, in the most fundamental sense, they do make statements about what

\footnotetext{
1 In fact, both logical positivists such as Carnap and empiricists like Quine reject ontology, and metaphysics more generally, precisely for not making empirically verifiable statements, though on slightly different grounds: While Carnap argues that ontological questions are simply meaningless (Carnap 1956), Quine maintains that the building blocks of reality cannot be investigated prior to and independent of an empirical scientific inquiry (Quine 1951).
} 
there is rather than about what we ought to do. ${ }^{2}$ In that sense, the concern with the attempt to derive moral conclusions from non-normative premises also cautions against grounding normative ethics or political philosophy in social ontology.

A second reason for keeping normative ethics separate from ontological inquiry is the view that ontological claims are more contested than normative ones, so that normative agreement becomes even more difficult when based on ontology. Rawls, therefore, deliberately seeks to construct a free-standing theory of justice, which brackets controversial social ontological (or other metaphysical) views in order to focus on creating an overlapping consensus regarding their normative implications (Rawls 2005). This view does not entail a rejection of the possibility of grounding normative ethics in ontological claims. However, it does suggest that an inquiry into ontological views can be sidestepped when developing a normative theory. In other words: normative claims are sufficiently intelligible without making ontological positions, which possibly undergird them, explicit.

Against this background, contemporary normative ethics and political philosophy within the Anglo-American tradition characteristically proceed on the assumption that it can and indeed should avoid relying on claims about the ontological, whether on logical or pragmatic grounds. In contemporary African philosophy, by contrast, the view that normative theory is not separate from but rather based on ontological claims is widespread. ${ }^{3}$

Note, however, that the very distinction between ontological and normative claims might not easily be translatable into African philosophical contexts in which a holistic account of being is conceived as comprising not only an ontology of visible and invisible beings but also epistemology and normative ethics as inseparable and interrelated parts of a whole. ${ }^{4}$ From this perspective, the presumed difference between an empirical and an ontological 'is' seems less of an issue as this distinction does not seem to map neatly onto African conceptual schemes. Many African ontologies comprise different categories of being in the spiritual as well as the physical world. As Gyekye has pointed out, while there is a distinction between the empirical and the non-empirical (spiritual) world, this distinction is not one of being: "in terms of being, both worlds are regarded as real" (Gyekye 1995: 197) ${ }^{5}$ This might partly explain why, within the debate on ontologized ethics, the is-ought gap and the distinction between the ontological and the normative are used largely interchangeably, in fact also by Metz (2014; See also Imafidon 2014a).

\footnotetext{
2 This holds, in particular for social ontology, the focus of this paper, which is concerned with the nature and properties of the entities in the social world—and is, in fact, often closely related to empirical work in the social sciences.

3 See for example Sindima (1989); Gyekye (1997: 36); Dukor (2007); Ekpo (2007); Ogugua (2007); Mkhize (2008); Murove (2009: 28); for a general discussion of this view within African traditions see Imafidon (2014b).

4 See for instance Ramose (2005).

5 See also Gyekye (1995, chapter 11) for an analysis of the translation of the existential and the predicate use of the verb 'to be' into Akan language and the untranslatability of some ontological issues such as the ontological existence of God.
} 
Holistic African accounts of being, however, challenge the very question of how, if at all, ontology and normative ethics are linked because both are inseparable parts of such holistic accounts of being. As Molefe argues, they are holistic both ontologically as well as morally speaking, as the view that reality is an interconnected web of life already comprises the moral claim that we should strive to maintain these interrelations and preserve the harmony and community they form. In that sense, conceiving of ontology and normativity as separate is already misleading. This is why Molefe concludes: "in the African thinking, the is/ought gap does not hold the water" (Molefe 2014: 129).

In other words: framing the question of how, if at all, normative ethics can be grounded in ontology in terms of the is-ought gap, risks concealing a conceptual mismatch - and may result in talking past each other. In fact, this is what, arguably, happens in Metz's criticism of Gyekye. In what follows, I will start from presenting the debate between Gyekye and Metz on its own terms before developing a proposal of how to make sense of the core issue raised in this debate in a way that is compatible with both approaches while leaving the framing of the issue in terms of the isought gap behind.

\subsection{Gyekye's Moderate Communitarianism and the Dual Nature of Human Beings}

Gyekye's political philosophy articulates a highly influential, original normative account of what he terms 'moderate communitarianism' (Gyekye 1997). It sets out to reconcile strong communitarian views commonly found within African philosophical traditions with the idea of individual rights that he thinks some African philosophers have underappreciated. On the one hand, Gyekye emphasizes the crucial importance of community. Members of a community "are expected to show concern for the well-being of one another, to do what they can to advance the common good, and generally to participate in the community life." (Gyekye 1997: 42) Sharing a way of life with others means acknowledging common roles, values, obligations and meanings and recognizing a commitment to the community, which is expressed through the desire to advance communal values (Gyekye 1997: 43). From such a communitarian point of view, values such as "love or friendship or concern (compassion) for others may be considered the first virtue of social institutions, rather than justice, which is fundamentally about, or crucially allied to, rights." (Gyekye 1997: 66)

On the other hand, Gyekye acknowledges the intrinsic worth of individuals and their rights as individuals (Gyekye 1997: 62-69). He emphasizes that "the responsibility an individual has toward the community and its members does not enjoin her to give over her whole life, as it were, to others and be oblivious of her personal well-being." (Gyekye 1997: 70) Individuals are not expected to conform by all means to the dominant ways of life within their community. While they should participate in shared life within a community, they retain individual rights and 
capacities, which allow them, to some extent, to critically engage with communal life. These rights are, in turn, delimited by responsibilities towards maintaining social values such as peace, harmony, stability, solidarity and reciprocity. (Gyekye 1997: 65) By giving equal weight to individual rights and duties towards others and the community, Gyekye's moderate communitarianism articulates an alternative to individualist views, as well as to strong communitarian views such as those found, most prominently, in Ifeanye Menkiti's work (Menkiti 1984).

Gyekye grounds his normative theory of how the relations between individuals and society should be structured in a social ontological account of the dual nature of human beings. Such a social ontology of the person pertains to the question of the constituents of the social world and the ontological relation between the individual and the social. ${ }^{6}$ Gyekye starts from a characterization of the ontological primacy of the community and the relational character of the human person, and that means from the "natural sociality of the person and from the fact that she is embedded in a set of necessary social relationships" (Gyekye 1997: 42). Living a life in community is not optional, it is not chosen; at least some of our social relationships are essential to the development of our personality and potentials. Indeed the "person is constituted, at least partly, by social relationships in which he necessarily finds himself" (Gyekye 1997: 38).

However, Gyekye emphasizes that the

individual is by nature a social (communal) being, yes; but she is, also by nature, other things as well; that is, she possesses other attributes that may also be said to constitute her nature. The exercise or application or consideration of these other attributes will whittle down or delimit the 'authoritative' role or function that may be ascribed to, or invested in, the community. (Gyekye 1997: 47 [original emphasis])

The 'other things' Gyekye has in mind are mental features, which constitute the individuals' capacity for autonomy, that is "such essential attributes of the person as rationality, having a moral sense and capacity for virtue and, hence, for evaluating and making moral judgments: all this means that the individual is capable of choice." (Gyekye 1997: 53) Thus, individuals are capable of reevaluating communal values and possibly even of rejecting them. In fact, it is precisely the individual "capacity for self-assertion" (Gyekye 1997: 54), which accounts for the fact that existing communal values change. Just as our social nature, this capacity is natural in the sense that it is not created by us or the community, even though it might be nurtured by the latter. Given that it plays a seminal role in the formation of plans or goals of the individual, Gyekye concludes that personhood is only partly but not fully defined by communal structures: "There is no denying the community's role in

\footnotetext{
${ }^{6}$ Note that this social ontological question about the nature of the most basic constituents of the social world, their social or non-social nature, and their relation to one another is distinct from the ontological question of the nature of the human being as a physically embodied and/or spiritual being and the relation between them. For Gyekye's dualistic and interactionist account of the Akan ontology of the human person see Gyekye (1995, chapter 6). I am grateful to an anonymous reviewer for pressing me to clarify this point.
} 
the complex process involved in the individual's realization of her goals and aspirations, though; yet, even so, the communal definition or constitution can only be partial." (Gyekye 1997: 53)

I characterize Gyekye's account of the dual sources of the self as a relational social ontological view. ${ }^{7}$ It is directed against both atomist, as well as collectivist, social ontologies. An atomist ontology conceives of the individual as being independent of and ontologically prior to any social context. Social life is an option, not an ontological necessity. Collectivists, by contrast, hold that individuals are constituted and fully defined by the community. In that sense, the community is ontologically prior to the individual. Gyekye's social ontological view articulates an alternative to both atomism and collectivism. He holds that we are both social and individual beings. We depend on social relations in a constitutive way, yet this does not mean that we are fully defined by social context. Rather, we retain individual agency within and vis-à-vis the social context on which we depend.

This view is relational in the sense that it conceives of the individual-and thus of the main building block of the social—as an entity in relation to others; it acknowledges our dependence on social relations without dissolving social relations between individuals within a broader notion of the community. In other words, while the individual person is partly constituted through social relationships, this dependence on social structures does not compromise her individual agency. ${ }^{8}$ It is precisely this relational social ontology that, on Gyekye's account, grounds the normative view he characterizes as moderate-as opposed to strong-communitarianism. Given that we are a product of both the social and the individual, we also have dual responsibilities, not just towards others and the community, but also towards ourselves (Gyekye 1997: 70).

This way of grounding normative content in social ontology is by no means particular to Gyekye's work. Other philosophers within African traditions defend similar views. ${ }^{9}$ In fact, Gyekye maintains that, generally speaking, "[m]oral questions... may, in some sense, be said to be linked to, or engendered by, metaphysical conceptions of the person." (Gyekye 1997: 36) The metaphysical questions he has in mind are precisely the core issues of social ontology, namely in how far individuals depend on larger social structures and which is ontologically prior; the individual or the community. The crucial question, however, is: how exactly are normative values and ideals linked to or engendered by such social ontological claims? What kind of link is it that ties normative theory to a social ontological account of our nature

\footnotetext{
7 Note that my use of the term 'relational'differs from Metz'use of it. Metz refers to relational moral theories as those which ascribe moral status on the basis of relational capacities (Metz 2012a) whereas Gyekye uses 'relational 'to describe how individuals are naturally oriented toward social relationships and thus to capture the social nature of individuals (Gyekye 1997: 38 and 67). One might argue that Gyekye's use of the term only refers to the communal as opposed to the individual sources of the self. My reading emphasizes an account that integrates both aspects. The communal, collectivist account does not see the individual as an entity in relation but rather defines the individual through the community.

${ }^{8}$ For an extensive discussion on why these are two separate ontological issues and a defense of a somewhat similar relational position, see Pettit (1993), Part II.

9 See references in Fn.3.
} 
as social beings? In other words: Why exactly does our dual nature entail a dual responsibility?

\subsection{Metz' Critique of the Link between the Normative and the Ontological}

The question of how exactly the normative is linked to the ontological constitutes the point of departure for Metz's critique of Gyekye's account. Metz argues that there is no direct link between ontology and normative theory, as nothing normative follows from a mere ontological account of the self or the world. He maintains that the bare fact that we are relational human beings does not imply anything with regard to what we should do. Thinking it does means committing the is-ought fallacy: "From purely ontological claims about what is, one cannot derive any epistemic support for a moral conclusion about what ought to be." (Metz 2014: 200) Metz argues that, to avoid this fallacy, Gyekye needs some kind of a bridge premise that can serve to mediate between the ontological 'is' and the normative 'ought' (Metz 2014: 194). Such a bridge premise would contain some normative considerations that explicitly specify the nature of the link between the ontological and the normative.

Metz suggests and dismisses three potential bridge premises. The first holds that ethics should reflect the social ontological account of human nature (Metz 2014: 195). It conceives of the link leading from the ontological to the normative as characterized by one being contoured to the other; the normative is to match certain features of the ontological. Metz, however, holds that this view is implausible as it fails to take account of the nature of normative claims as a source of guiding actions and a standard for critique: "sound norms are usually understood to be those that direct or constrain their objects in accordance with good reason." (Metz 2014: 196) In other words, if norms were merely mirroring the nature of their objects, the distance between norms and their objects, which is crucial for the purpose of articulating principles of guidance and critique, disappears. If we are to retain the action guiding, critical thrust of normative theory, any attempt to ground normative claims in ontology needs to allow for some kind of distance between norms and their objects.

The second bridge premise that Metz discusses sees ethics as realizing human nature. On this perfectionist view, the ontological account of who we are provides the basis for what we should strive to be: genuinely human. In contrast to the view expressed in the first bridge premise, a normative theory does not merely reflect who we are, but rather articulates how to fully become who we really are. It thus seems to allow for a certain distance between who we are and who we should become. Yet, Metz criticizes that such a perfectionist take on the relation between the ontological and the normative would advocate realizing whatever our nature is, including its bad aspects. Such a view would hardly serve as the basis of a plausible account of ethics. Thus, ultimately, the second bridge premise falls prey to a similar problem as the one faced by the first bridge premise.

The final bridge premise that Metz discusses maintains that ethics should have us pay back those responsible for the course of our lives in proportion to their contribution (Metz 2014: 198). While this premise directly picks up on Gyekye's view that 
it is our dual nature that grounds our dual responsibility, Metz rightly points out that it cannot serve as a ground of morality in general. It may ground a responsibility to support what contributed to my personal development, however, it seems unclear why it would also ground the obligation to respect individual rights in general (Metz 2014: 200).

Given that all three premises that aim to bridge the is-ought gap between the ontological account of who we are and the normative account of what we should do fail, Metz concludes that it is "fruitless to try to ground a moral-political theory on claims about the nature of the self in the way Gyekye attempts." (Metz 2014: 200) In fact, his doubts about grounding normative theory in ontology hold more generally. Metz maintains that a normative position, like that of moderate communitarianism, could also be defended on the basis of a different ontological position. Hence, he argues that no matter what kind of ontological position we hold, "nothing yet follows with respect to the way we ought to treat people." (Metz 2014: 201)

\section{How the Social Ontological Circumscribes the Normative}

While I generally agree with Metz's arguments against the bridge premises, I will challenge his conclusion by providing an account of the relation between social ontology and normative theory that leaves the framework of the is-ought gap which he uses to discuss Gyekye's view behind. I will proceed in two steps: I will show that, even in the absence of persuasive bridge premises, something does indeed follow from (social) ontology with regard to normative thought, though not in a positive but rather in a negative sense (3.1). And, as I will show again with the example of Gyekye's political philosophy, it is precisely the sensitivity to these negative normative implications of ontology in interpreting substantive normative content that gets lost when the link between normative theory and ontology is severed (3.2.).

\subsection{From (Relational) Social Ontology to (Relational) Normative Theory}

Metz's criticism of Gyekye's way of grounding normative theory on ontology is directed towards a reading that sees the former as being directly derived from the latter. In fact, Metz acknowledges that his conclusion does not imply that ontological claims are utterly irrelevant to normative theory, but simply that the latter cannot be derived merely from the former (Metz 2014: 203). Given what I said earlier about the difficulties of translating the binary distinction between is and ought into an African holistic ontology, this framing might in fact not do full justice to Gyekye's account.

However, there is an alternative way to conceive of the link between the social ontological and the normative without strictly speaking, deriving the ought from the $i s$. And it is Metz himself who provides a key for doing so, though, arguably, unwittingly. In discussing what it is for a normative theory to reflect ontological views, Metz suggests that while a normative theory cannot simply be taken to mirror ontological facts, it should take account of human nature so as not to be "overly idealistic 
or utopian" (Metz 2014: 196). In this section, I will explore whether this idea can provide the basis for a more than trivial account of how normative theory is tied to ontology. I think it can.

My proposal starts from the observation that our normative thought is constrained by our account of who we are in the social world. In order to have any guiding force on us, norms cannot demand what we, given our nature as human beings, will never be able to do. A norm demanding us to revive someone who died an avoidable death in a car accident would not be a plausible norm, given that we do not have the power to revive the dead. Ought implies can, and the 'can' is constrained by the kind of beings we are. In this somewhat trivial sense, as Metz rightly emphasizes, normative theory needs to take account of human nature. However, the point I want to make is deeper than that. The kind of social ontological position we hold, I maintain, circumscribes the kind of normative ideals we can plausibly defend. Let me explain.

Gyekye develops a relational social ontology. The basic entities of the social world are neither individuals, taken separately, nor communities as such. Rather, his view is based on the claim that human beings have a dual nature: individual and social. That means that the basic entities are beings-in-relation, that is, distinct entities who cannot but relate to one another. As social beings, born into a social world, we are naturally confronted with the question of how to live with others:

The natural relationality of the person thus immediately plunges her into a moral universe. Social life itself, thus, prescribes or mandates a morality that, clearly, should be weighted on responsibility for others and for the community, a morality that should orient the individual to an appreciation of shared, and not only individual ends. (Gyekye 1997: 67)

Following Gyekye's social ontology, morality itself, and normativity more generally, is not something that we choose to embrace. Sure, we do retain a capacity for selfassertion, and thus, while we are naturally confronted with a social-normative context, we can shape this context and how we relate to it. Yet, we are not first individuals and then decide, by our own free choice, to enter the realm of the normative as classic contract theory suggests. Rather, as social beings, we are born into a web of social relations - and corresponding normative expectations- that raise and address the question of how to relate to others. That, in turn, means that the normative questions we ask start from the way we find ourselves confronted with normative issues and that, in turn, depends on how we conceive of our nature as human beings. It is because we are relational beings who find themselves in social relations while still being able to shape them that normative thought needs to address first and foremost how to relate to one another.

This reading of Gyekye suggests that a normative theory building on a relational social ontology will comprise at least some core relational value(s). By relational values I mean values that apply precisely to how people relate to another. As such, relational values are distinct from both individual and collective values. Individual values, such as material welfare or happiness, focus essentially on the state of individuals. Social relations may play an instrumental role in realizing individual values; yet, the value itself does not make any essential reference to others. Relational values, by contrast, cannot be enjoyed in isolation from others as they apply to social 
relations themselves. Thus, the enjoyment of relational values requires the presence of people who are involved with one another. And yet, relational values also differ from collective values such as communal cohesion or cultural harmony, which inhere in the collectivity taken as a group, over and above its individual members. Both are social values in the sense of describing a property of the social as opposed to the individual. But relational values are values that individuals enjoy in relation to others, not values that groups enjoy qua groups.

There are various different values that are relational in this sense. One might think of caring and sharing as advocated by proponents of Ubuntu (Ramose 2005: 102; Metz 2007; Murove 2014: 40), or caring in the sense defended by some strands of feminism (Gilligan 1982) or of the neo-republican ideal of non-domination (Pettit 1997) ${ }^{10}$. There might not be a direct link between a particular relational ontology and a particular relational value. The mere fact that we are relational beings in the sense explained above does not necessarily mean we have a right to non-domination or an obligation to care for others. In that sense, the specific ought may not directly derive from the $i s$.

Yet, the view that as relational beings we cannot but be part of some social context and thus relate to others implies that normative theory will need to take account of this relational nature by taking social relations as its primary subject matter. That means that some relational value will serve as the core standard, which also delimits the normative import of other, non-relational values. Material welfare or cultural harmony may also be relevant within such a relational normative theory, but their normative value will have to be assessed at least in part from the perspective of individuals who are necessarily in relation with each other-and thus from the perspective of a relational value. This relational value will serve as the yardstick for striking a balance between individualist and collectivist normative claims. In other words, a relational ontology implies a commitment to a relational normative theory that is oriented towards how people relate to one another and thus comprises at least some core relational value(s).

A similar point holds with regard to the implications of alternative views. An atomist ontology implies a normative theory that is based on at least some core individual value(s), i.e. an individualist normative theory. If we consider the individual in isolation an ontological possibility or even an ontological reality, this view on who we essentially are will feed into any normative assessment of a given social context. A normative theory will have to show that social arrangements like a state are normatively superior to merely leaving individuals to their own. Such a judgment will have to be made in terms of individual values, which could, at least in principle, be enjoyed by individuals under non-social conditions, such as utility or material welfare. ${ }^{11}$ Hence, an atomist ontology commits the normative theorist to defend an individualist view with individual value(s) at its core. Classic contract theories like Hobbes' are an example. Relational or collective values may also figure in such an

\footnotetext{
${ }^{10}$ For a comparative analysis of the relational character of Ubuntu and Republicanism see Gädeke (2019).

11 See Pettit (1993: 305f) for a similar point. In fact, Pettit argues that it is precisely the atomist social ontology that Hobbes bequeathed to the English tradition of political thought, which accounts for its almost exclusive focus on individual values - whereas the continental tradition readily embraced social, i.e. relational and collective values.
} 
individualist normative theory; however, they are circumscribed by the individual value(s) deemed crucial. Friendship or cultural harmony, for instance, might be of normative import; yet they cannot serve as the ultimate standard of assessing social institutions. The basic standard to make such normative judgments will have to be an individual one.

A collectivist ontology, in turn, commits the normative theorist to a communalist or (strong) communitarian normative theory, which is based on at least some core collective value(s). If there are no individual agents with some kind of autonomous agency, the idea of assessing social arrangements exclusively in terms of how the individual fares in them as compared to how he/she fares in non-social arrangements is a non-starter. Even relational values cannot serve as the ultimate standard of evaluation, given that social relations are not reducible to individuals being in social relations. Rather, there is an entity over and beyond the individual that will need to figure in normative assessments and circumscribe the normative import attributed to other, non-collective values - or else, normative theory fails to address the kinds of agents to which it is meant to apply. Hence, starting from a collectivist ontology, collective values are a necessary, though possibly not a sufficient, part of any normative theory-just as relational values are a necessary part of normative theories based on a relational ontology.

This discussion shows that the social ontological does indeed circumscribe the normative. It may not positively entail any particular normative content. Rather, it leaves normative content underdetermined. In that sense, the ought may not directly derive from the is. However, the ontological does negatively restrict the kind of normative theory we may plausibly endorse. In other words, for a normative theory to take account of social ontology, it does not merely mean respecting the limits of human agency. It also entails a commitment to the kind of normative theory, whether individualist, relational or (strong) communitarian/communalist, that corresponds to the ontological account of our social or non-social nature.

\subsection{Towards a Relational Interpretation of Well-Being}

I argued that a relational ontology, such as famously defended by Gyekye, may not entail any particular normative content; however, it does entail a particular form of normative thought, namely, a relational one. This, however, does not mean that the link between social ontology and normative theory is purely formal, restricting only the kind of normative theory that one can plausibly endorse. In fact, this view has substantive implications insofar as it also circumscribes how to interpret normative content in a way sensitive to its social ontological foundations - a point that is easily overlooked when this link is severed. 
At first sight, one might think that Gyekye's account of morality and politics fails to reflect his relational ontology in the way I have laid out in the previous section. His moderate communitarianism is meant to take account of our dual nature by formulating a dual responsibility, towards others and the community, as well as towards ourselves. In that sense, it does formulate a middle position between individualism and communitarianism. And yet, the ultimate value that serves to evaluate social contexts does not seem to be a relational one. To become a person, Gyekye argues, an individual needs to develop virtues such as "kindness, generosity, compassion, benevolence, and respect and concern for others; in short, any action or behavior conducive to the promotion of the well-being of others." (Gyekye 1997: 50) This passage invokes the idea that relational values such as kindness or compassion are ultimately circumscribed by an individual value, namely well-being. They matter if and insofar as they prove conducive to the well-being of individuals. Given such statements, Gyekye's moderate communitarianism has been characterized as a welfarist or utility-based view (Metz 2007: 330; Metz 2012b) — a classic example of a normative theory based on an individual value, not a relational one.

One might want to insist that, ultimately, Gyekye does not defend any overarching value; instead, the individual value of utility always needs to be balanced against collective values. Emphasizing the relational ontology and its implications for normative theory, however, puts Gyekye's account into a different light. Provided that well-being is indeed a core normative ideal in his account ${ }^{12}$, it suggests that it needs to be interpreted in light of his social ontology and that means, in a relational way. In this reading, the well-being of others is not itself understood as a non-social good that they might enjoy in isolation. Relational well-being does not merely mean being well in terms of having one's needs satisfied. Rather, it is tied to a certain kind of relationship in the sense that it means being well with and through others. Relational well-being is not merely contingently fostered by social relations, but rather constituted through them, even though only in parts, as being in relation does not fully define what it means to be well. Social relations as such are neither a means, nor an end in themselves. They are part and parcel of what it is to be human. And that means that individual well-being can only be realized in and through particular kinds of relationships. Hence, the "caring attitude or conduct that one feels one ought to adopt with respect to the well-being of another person or other persons" (Gyekye 1997: 66) that Gyekye invokes means more than merely providing goods for others so as to improve their well-being taken as an individual good. What matters is that we care about and foster the well-being of others, not just that the individual is well. Competing individual or collective claims will have to be assessed from this perspective.

While this account of relational well-being might not be explicitly stated in Gyekye's own writings, it is certainly in the spirit of his writings. Emphasizing the relational nature of his conception of well-being suggests understanding Gyekye's normative view as an account that integrates the individual and the communal perspective rather than merely striking a delicate balance between them. From such a

12 I do not address the issue whether this is indeed the best reading of Gyekye's work. 
relational understanding, individual and collective aspects of Gyekye's normative view are not necessarily in tension with each other precisely because we incorporate both. We are and conceive of ourselves as relational beings; as individuals in relation. Hence, normative theory is about our well-being as individuals in relation to others, and thus, fundamentally, about a relational value.

Other values such as "compassion, solidarity, reciprocity, cooperation, interdependence, and social well-being" that Gyekye counts among the principles of his moderate communitarianism, are also decidedly relational in character; they advocate a "life lived in harmony and cooperation with others, a life of mutual consideration and aid and of interdependence, a life in which one shares in the fate of the other" (Gyekye 1997: 75f). Taking account of how a relational ontological view circumscribes normative theory thus suggests an interpretation of Gyekye's normative work that emphasizes its relational aspects, including a relational conception of well-being, which posits it as an original alternative, not just a balance between individualist and strong communitarian views - and one that easily gets overlooked if the link between normative theory and social ontology is severed.

\section{Conclusion}

Starting from Metz's rejection of Gyekye's claim that normative theory is grounded in social ontology, I suggested a novel way of reading his claim that the normative is indeed linked to the ontological, one that leaves the framing of the issue in terms of the is-ought distinction behind. The social ontological position we hold, I argue, circumscribes what kind of normative theory we may plausibly defend. A relational social ontology implies a relational normative approach, based on at least some relational value(s). Similarly, an atomist social ontology entails a commitment to an individualist normative view that is based on at least some individual value(s) while a collectivist social ontology implies a normative view based on at least some collective value(s). I thus showed that something normative does indeed follow from our social ontological views, even though only in the negative sense of constraining the kinds of values we may deem fundamental.

Yet, taking this link between the social ontological and the normative seriously, in turn, has implications on how to interpret the substantive content of a normative theory. I illustrated this claim by showing that with regard to Gyekye's normative theory, it suggests a decidedly relational reading of the core value of well-being that resolves the alleged tension between communal values and an overarching allegedly individual value. In how far, exactly, my claim has similar implications for reading other normative theories remains to be shown, though it will likely entail emphasizing interpretations that correspond with the ontological basis in a similar way. Thus, my argument not only offers a way of engaging with ontologized ethics over and beyond framing the issue as one of the is-ought gap; it also casts doubt on the pragmatic claim that normative content can indeed be sufficiently intelligible without making its social ontological basis explicit. 
Any attempt to expand the further reach of my argument, however, needs to take account of the fact that my claim regarding how the ontological circumscribes the normative is of limited reach in at least two respects. First, I argued that the normative implications of an ontological view are limited to the kind of normative theory that one may plausibly defend. My argument does not entail the claim that some normative content can directly be derived from ontological claims. Authors who defend the stronger claim that a substantive ought directly follows from the is will certainly find my argument insufficient. I have merely shown that there is indeed a link between the ontological and the normative that needs to be taken seriously and that it does have consequences for how to read a normative theory. Any stronger claim about the link between the ontological and the normative will need further arguments which I could not address in this article.

Secondly, the link between the ontological and the normative I suggested is limited to a certain realm of ontology, namely social ontology. Social ontology is concerned with the issue of how the individual being relates to the social. Ontology as such, however, is a much broader field that also comprises the issues of how humans relate to nature and whether there is a non-visible, supernatural world and if so, how humans relate to it. In fact, both aspects are of particular importance in African philosophy, where complex views of how these different spheres are interrelated are defended. ${ }^{13}$ It remains to be explored in how far a similar argument about how an ontological view circumscribes the kind of normative theory one may defend holds with regard to ontological claims about the relation between humans and nature or between humans and the supernatural world.

One might think that a relational ontology of human-nature relations that does not see them as separate, ontologically prioritizing the one over the other, but rather emphasizes their interconnectedness, also entails a commitment to a relational normative theory with regard to how to respond to nature. ${ }^{14}$ Ontological claims with regard to the supernatural might have similar implications for the way we should respond to supernatural entities. Yet, Gyekye seems to doubt that the link between the ontological and the normative holds beyond the realm of social ontology. Even though he defends the view that a normative theory is based on an ontological account of the human being, he denies a similar link between normative theory and a broader metaphysical view that includes claims about the supernatural world: "The African metaphysic, to be sure, is a theistic one, and yet it does not nurture theistic or supernatural ethic" (Gyekye 2010). He aims to show that African normative theory is essentially humanist in character; that religion does not provide the necessary justification for moral beliefs. Rather, he holds onto the view that religion itself is subject to human normative censure. This view, however, does not rule out that ontological claims pertaining to the supernatural constrain the form of normative theory that one may plausibly hold. Gyekye merely questions whether substantive

\footnotetext{
13 See for instance Ramose (2005: Chapter 3) for an onto-triadic account that involves humans, the living-dead and the yet-to-be-born and Gyekye (1995: chapter 5-8).

14 See Behrens (2014a, b) for an argument that might be read in this spirit. For a critical stance on the idea of normative implications of the interrelatedness in the natural world, see Metz (2014: 202).
} 
normative content can be derived from a supernaturalist ontology. This move, in turn, supports the reading I suggested with regard to the link between social ontology and normative theory. If Gyekye, by contrast, understands the way his normative theory is grounded in ontology in a stronger, substantive sense, he would need to show where the relevant difference between social ontology and the supernatural lies.

Once it is acknowledged that ontology and normative theory might not be as neatly separated as parts of Anglo-American philosophy make us believe, there is room to explore how exactly normative theory is linked to other parts of ontology. I did not aim to provide a full account of how these two spheres are interlinked. My aim was more modest: I suggested a way to make sense of Gyekye's claim that does not commit the naturalistic fallacy. At least with regard to social ontology, I argued, there is a relevant, albeit only negative, link between the ontological and the normative. This claim might invite further research on expanding the reach of the argument. In the limited sense that I outlined, however, Gyekye's claim that his moderate communitarianism is grounded in (even if not derived from) ontology seems justified.

Acknowledgements An earlier version of this paper was presented at the 23rd ISAPS conference African Philosophy in an Intercultural World at the University of Vienna in 2017; I am grateful to the audience for helpful suggestions and to Thaddeus Metz and two anonymous reviewers for thoughtful comments on the manuscript.

Open Access This article is licensed under a Creative Commons Attribution 4.0 International License, which permits use, sharing, adaptation, distribution and reproduction in any medium or format, as long as you give appropriate credit to the original author(s) and the source, provide a link to the Creative Commons licence, and indicate if changes were made. The images or other third party material in this article are included in the article's Creative Commons licence, unless indicated otherwise in a credit line to the material. If material is not included in the article's Creative Commons licence and your intended use is not permitted by statutory regulation or exceeds the permitted use, you will need to obtain permission directly from the copyright holder. To view a copy of this licence, visit http://creativecommons.org/licen ses/by/4.0\%.

\section{References}

Behrens, K.G. 2014a. An African relational environmentalism and moral considerability. Environmental Ethics 1: 63-82.

Behrens, K.G. 2014b. Towards an African relational environmentalism. In Ontologized ethics: New essays in African meta-ethics, ed. J. Bewaji and E. Imafidon, 55-72. Lanham et al.: Lexington.

Carnap, R. 1956. Empiricism, semantics, and ontology. In Meaning and necessity: A study in semantics and modal logic, ed. id., 203-221. Chicago: University of Chicago Press (2nd edition).

Ekpo, I.J. 2007. Process theory and african metaphysical worldview: The foundation of African communalism. In Perspectives on African communalism, ed. I. Odimegwu, 36-53. Victoria: Trafford Publishing.

Dukor, M. 2007. The concept of justice in African philosophy. In Perspectives on African communalism, ed. I. Odimegwu, 54-72. Victoria: Trafford Publishing.

Gädeke, D. 2019. Relational normative thought in Ubuntu and neo-republicanism. In Debating African philosophy. Perspectives on identity, decolonial ethics and comparative philosophy, ed. G. Hull, 269-288. Abingdon/New York: Routledge.

Gilligan, C. 1982. In a different voice. Cambridge: Harvard University Press. 
Gyekye, K. 2010. African ethics. Stanford encyclopedia of philosophy, ed. E. Zalta, https://plato.stanford. edu/archives/fall2011/entries/african-ethics/ (accessed July 04, 2019).

Gyekye, K. 1997. Tradition and modernity. Philosophical reflections on the African experience. New York/Oxford: Oxford University Press.

Gyekye, K. 1995. An essay on African philosophical thought. The Akan conceptual scheme, Revised ed. Cambridge: Cambridge University Press.

Hume, D. 2000 [1738-1740]. A treatise of human nature. Ed. By D.F. Norton and M. Norton. Oxford: Oxford University Press.

Imafidon, E. 2014a. Introduction. In Ontologized ethics: New essays in African Meta-Ethics, ed. J. Bewaji and E. Imafidon, ix-xiv. Lanham et al.: Lexington.

Imafidon, E. 2014b. On the ontological foundation of a social ethics in African traditions. In Ontologized ethics: New essays in African meta-ethics, ed. J. Bewaji and E. Imafidon, 37-54. Lanham et al.: Lexington.

Metz, T. 2014. Questioning African attempts to ground ethics on metaphysics. In Ontologized ethics: New essays in African meta-ethics, ed. J. Bewaji and E. Imafidon, Elvis, 189-204. Lanham et al.: Lexington.

Metz, T. 2012a. An african theory of moral status. A relational alternative to individualism and holism. Ethical Theory and Moral Practice 15: 387-402.

Metz, T. 2012b. Developing African political philosophy: Moral-theoretic strategies. Philosophia Africana 14 (1): 61-83.

Metz, T. 2007. Toward an African moral theory. The Journal of Political Philosophy 15 (3): 321-341.

Menkiti, I.A. 1984. Person and community in African traditional thought. In African philosophy: An introduction, ed. R.A. Wright, 3rd edition, 171-181. Lanham: University Press of America.

Mkhize, N. 2008. Ubuntu and harmony: an African approach to morality and ethics. In Persons in community. African ethics in a global culture, ed. R. Nicolson, 35-44. Scottsville: UKZN Press.

Molefe, M. 2014. Critical reflections on Gyekye's humanism: Defending supernaturalism. In Ontologized ethics: New essays in African meta-ethics, ed. J. Bewaji and E. Imafidon, 121-132. Lanham et al.: Lexington.

Moore, G.E. 1903. Principia ethica. New York: Cambridge University Press.

Murove, F.M. 2014. Ubuntu. Diogenes 59 (3-4): 36-47.

Murove, F.M. 2009. Beyond the savage evidence ethic. A vindication of African ethics. In African ethics. An anthology of comparative and applied ethics, ed. F.M. Murove, 14-32. Scottsville: UKZN Press.

Ogugua, I.N. 2007. The metaphysical basis of African Communalism. In Perspectives on African communalism, ed. I. Odimegwu, 24-35. Victoria: Trafford Publishing.

Pettit, P. 1997. Republicanism. A theory of freedom and government. Oxford: Oxford University Press.

Pettit, P. 1993. The common mind. An essay on psychology, society, and politics. Oxford: Oxford University Press.

Quine, W.O. 1951. Two dogmas of empiricism. The Philosophical Review 60: 20-24.

Ramose, M. 2005. African philosophy through Ubuntu, Revised ed. Harare: Mond Books Publishers.

Rawls, J. 2005. Political liberalism, Expanded ed. New York: Columbia University Press.

Sindima, H. 1989. Community of life. The Ecumenical Review 41 (4): 537-551.

Publisher's Note Springer Nature remains neutral with regard to jurisdictional claims in published maps and institutional affiliations. 